\title{
Psychometric Properties of the Slovak Version of sEMBU on General Adult Sample
}

\author{
Gabriela Rozvadský Gugová - Martin Eisemann*
}

Received: June 27, 2016; received in revised form: September 29, 2016; accepted: October 3, 2016

\begin{abstract}
The factorial stability and reliability of the 23-item s(short)EMBU previously demonstrated to be satisfactory in the samples of students from Greece, Guatemala, Hungary, Italy (1999), East-Germany and Sweden (Arrindell et al., 2001). The Slovak translation of the original sEMBU was published in 2007 (Poliaková, Mojžišová, \& Hašto, 2007). We decided to explore the psychometric properties of the translation of sEMBU on a general adult sample $(\mathrm{N}=970)$ in Slovakia, because the translated version of sEMBU is already utilized in research projects in Slovakia. The results show a very good alpha reliability of sEMBU. In the Slovak translation, we found similar scores of Rejection and Emotional warmth and Overprotection. A factor analysis with forced 3-factor solution sorted items to scales exactly as authors of sEMBU presupposed. Overprotection (father) has the highest share for classification and differentiation in the cluster. Emotional warmth (mother) has the highest share for classification and differentiation in the cluster. We discussed our results with the results from other studies and we suggest to continue in the research of the Slovak version of sEMBU focused on types of attachment, especially on the secure type of attachment.
\end{abstract}

Key words: parenting, attachment styles, sEMBU, experiences in attachment, psychometrics, parent and child interaction.

\section{Introduction}

John Bowlby (1969) and Mary Ainsworth are the founders of The Attachment theory (Ainsworth, Bell, \& Stayton, 1975). John Bowlby formulated the basic tenets of the theory (Bowlby, 1991), and Mary (Ainsworth, Bell, \& Stayton, 1975) helped expand the theory itself, she formulated the concept of maternal sensitivity to infant signals and its role in the development of the infant-mother attachment patterns. Ainsworth, Blehar, Waters and Wall identified three major

Gabriela Rozvadský Gugová, Dubnica Institute of Technology in Dubnica nad Váhom, Dubnica nad Váhom, Slovakia; gugova@dti.sk

Martin Eisemann, Faculty of Health Sciences, University of Tromsø, Tromsø, Norway; martin.eisemann@uit.no 


\section{Acta Technologica Dubnicae \\ volume 6, 2016, issue 3}

styles of attachment in infancy - secure, anxious-avoidant, and anxiousambivalent - and traced them to the caregivers' parenting behavior (Ainsworth, Blehar, Waters, \& Wall, 1978).

A relationship formative life experience has an impact on the regulation of neurobiological models and formulas to use defense mechanisms. More information regarding the memories of one's parents' behavior will allow us to know the process of creating a more focused model of education. The educational practices in childhood and the parent - child relationship convince us of their importance as the determinants of the personality characteristics and possible available for later mental disorders. As, in our environment, only a few authors pay attention to attachment (Hašto, 2005; Mojžišová, 2006; Poliaková, Mojžišová, \& Hašto, 2007), we agreed to a apply factor analysis on the translated tool. We assumed to reach similar results as the authors' original version of EMBU (Jacobson, Lindstrom, von Knorring, Perris, \& Perris, 1980; Arrindell, Emmelkamp, Monsma, \& Brilman, 1983; Arrindell, Emmelkamp, Brilman, \& Monsma, 1983).

In our research, we used the sEMBU questionnaire. This is the shortened version of the original 81-item questionnaire EMBU subscales with 15 and two additional issues related to consistency and strictness of parental educational behavior. The sEMBU consists of 23 questions grouped into 3 subscales Rejection, Emotional warmth and Overprotection. The questions are answered separately for fathers and mothers on a 4-point Likert scale. EMBU is a Swedish acronym for Egna Minnen Beträffande Uppfostran (My memories of upbringing: My memories as I was raised).

Many national standardizations in different countries and samples found general support for the validity of sEMBU (Arrindell, Emmelkamp, Brilman, \& Monsma, 1983; Arrindell, Emmelkamp, Monsma, \& Brilman, 1983; Arrindell et al., 2001; Eisemann, Perris, Perris, \& von Knorring, 1984; Perris, Arrindell, van der Ende, Maj, Benjaminsen, Ross, Eisemann, \& del Vecchio, 1985; Richter, \& Eisemann, 2001) and their items. As the translated version of sEMBU is already utilized in research projects in Slovakia, we found it necessary to look for the psychometric properties of the Slovak version of sEMBU. The shortened form sEMBU was filled by students in 11 countries in Europe, Asia, Australia and South America through an international study of individual personality and fears evaluation (Arrindell et al., 1999). The descriptive statistics of the sample made by Arrindell et al. (1999) showed that all the items were fed by factors of Rejection or Emotional warmth. General patterns of correlations between factors in the long version of EMBU were as follows: a significantly and considerably negative correlation between Rejection and Emotional warmth, statistically significant and positive association between Rejection and Overprotection and 


\section{Acta Technologica Dubnicae \\ volume 6, 2016, issue 3}

statistically insignificant and negligible association between Emotional warmth and Overprotection. The coefficients of internal consistency (Cronbach's $\alpha$ ) for all scales were satisfactory $(\geq 0.72)$. Different versions of EMBU have been standardized and translated in more than 25 countries (Rojo-Moreno, LivianosAldana, Cervera-Martínez, \& Dominguez-Carabantes, 1999; Livianos-Aldana \& Rojo-Moreno, 2003; García, Aluja \& Del Barrio, 2006; Oldehinkel, Veenstra, Ormel, de Winter, \& Verhulst, 2006).

\section{Methods}

The goal of the study is to analyze the psychometric properties of the Slovak translation of sEMBU (Poliaková, Mojžišová, \& Hašto, 2007) and investigate of the existing modeling patterns of education in Slovakia in the context of the future use of sEMBU as a research and diagnostic tool, as well as in the context of attachment theory.

Our final sample consists of 970 participants, who were recruited during their external pre-gradual studies in Dubnica Institute of Technology (DTI) between 2010-2014. Participants were selected on availability basis and willingness to participate without any rewards. All of them finished high school with final Aexam. They lived throughout whole Slovakia as DTI has many small local consultation centers in all regions of Slovakia. Age properties of the sample can be seen in Table 1. All participants filled in the Slovak translation (Poliaková, Mojžišová, \& Hašto, 2007) of sEMBU (Arrindell et al., 1999).

We analyzed the psychometric properties of the Slovak version of sEMBU applying the following procedures: descriptive statistics, item-total correlation, alpha reliability, exploratory factor analysis, attachment styles analysis and correlation analysis of the relationship of sEMBU and the demographic properties. We focused on the general psychometric properties of sEMBU. The results are commented on and shortly discussed continuously in the study for better clarity and the part Discussion is focused only on selected topics.

\section{Outputs of the study}

The research sample for the study consisted of 507 women and 463 men. The mean age of participants was $\mathrm{M}=31.743 ; \mathrm{SD}=8.7317$ (from 18 to 62). Descriptive and frequency statistics for sEMBU subscales and percentiles in the whole sample are displayed in Table 2. The mean score sEMBU in our study for Rejection (father) was: $\mathrm{M}=13.88, \mathrm{SD}=3.250$; Rejection (mother) was: $\mathrm{M}=14.44$, $\mathrm{SD}=3.768$; Emotional warmth (father): $\mathrm{M}=14.24, \mathrm{SD}=3.190$; Emotional warmth (mother): $\mathrm{M}=14.24, \mathrm{SD}=3.214$; and Overprotection (father) was: $\mathrm{M}=18.90$, $\mathrm{SD}=3.509$; Overprotection (mother): $\mathrm{M}=17.69, \mathrm{SD}=3.990$. Our results are higher as to results published by Perris (Perris, Jacobson, Lindstrom, Von Knorring, \& 


\section{Acta Technologica Dubnicae \\ volume 6, 2016, issue 3}

Perris, 1980), who reports that the score for Rejection (father) was: $M=11.11$ and for Rejection (mother) was $\mathrm{M}=11.78$; and for Overprotection (father) was: $\mathrm{M}=10.70$ and Overprotection (mother) was: $\mathrm{M}=11.70$. But our results are close to the results published by Castro (Castro, de Pablo, Gómez, Arrindell, \& Toro, 1997), who reports that the score for Rejection (father) was: $\mathrm{M}=16.32, \mathrm{SD}=3.00$ and for Rejection (mother) was $\mathrm{M}=16.38, \mathrm{SD}=2.74$.

Table 1

Age description of whole research sample $(N=970)$

\begin{tabular}{cc}
\hline s EMBU & Total \\
$\mathbf{N}$ & 970 \\
Age range & $18-62$ \\
Age mean & 31.743 \\
Age SD & 8.7317 \\
\hline
\end{tabular}

Table 2

Frequency statistics of the sEMBU scales and percentiles in the whole sample $(N=970)$

\begin{tabular}{|c|c|c|c|c|c|c|c|}
\hline s EM & & $\begin{array}{l}\text { Rejection } \\
\text { (father) }\end{array}$ & $\begin{array}{c}\text { Rejection } \\
\text { (mother) }\end{array}$ & $\begin{array}{c}\text { Emotional } \\
\text { warmth }\end{array}$ & $\begin{array}{c}\text { Emotional } \\
\text { warmth }\end{array}$ & $\begin{array}{c}\text { Overprotec } \\
\text { (father) }\end{array}$ & $\begin{array}{c}\text { Overprotec } \\
\text { (mother) }\end{array}$ \\
\hline $\mathrm{N}$ & & 967 & 968 & 968 & 968 & 968 & 968 \\
\hline Scale M & & 13.88 & 14.93 & 14.24 & 14.44 & 18.90 & 17.69 \\
\hline Scale SD & & 3.250 & 3.768 & 3.190 & 3.214 & 3.509 & 3.990 \\
\hline & Ptil 10 & 9.00 & 9.00 & 10.00 & 11.00 & 14.00 & 13.00 \\
\hline & Ptil 20 & 11.00 & 12.00 & 12.00 & 12.00 & 16.00 & 14.00 \\
\hline & Ptil 30 & 13.00 & 13.00 & 13.00 & 13.00 & 17.00 & 15.00 \\
\hline & Ptil 40 & 13.00 & 15.00 & 13.00 & 13.00 & 18.00 & 16.00 \\
\hline Percentiles & Ptil 50 & 14.00 & 15.00 & 14.00 & 14.00 & 19.00 & 17.00 \\
\hline & Ptil 60 & 15.00 & 16.00 & 15.00 & 15.00 & 20.00 & 18.00 \\
\hline & Ptil 70 & 16.00 & 17.00 & 15.00 & 15.00 & 21.00 & 19.00 \\
\hline & Ptil 80 & 16.00 & 18.00 & 16.00 & 17.00 & 22.00 & 21.00 \\
\hline & Ptil 90 & 18.00 & 20.00 & 19.00 & 19.00 & 23.00 & 23.00 \\
\hline
\end{tabular}

Note: *Ptil $=$ Percentil

\section{Correlations}

We found correlation between Rejection (father and mother) and Emotional warmth and Overprotection, we found correlation between "My parents separated" and Rejection (mother) 0.184 and Emotional warmth (father) 0.200, as well as between "I have... brothers and sisters" and "I have ... brothers and sisters older than me" 0.588 . 


\section{Acta Technologica Dubnicae \\ volume 6, 2016, issue 3}

Further, we found correlation between: Rejection (father) and Rejection (mother) subscale ( $\mathrm{r}=.655, \mathrm{p}<.001)$; Emotional warmth (father) and Rejection (father) subscale ( $\mathrm{r}=-.212, \mathrm{p}<.001)$; Emotional warmth (father) and Emotional warmth (mother) subscale ( $\mathrm{r}=.643, \mathrm{p}<.001)$; Emotional warmth (mother) and Rejection (father) subscale ( $\mathrm{r}=-.293, \mathrm{p}<.001)$, see results in Table 3. A mild to medium significant level of negatively correlation between Rejection and Emotional warmth scale is found in numerous studies (see results in Arrindell et al., 2001). We find these results to be supportive for claim of the Slovak version of sEMBU validity.

Table 3

Correlations of the sEMBU scales in the whole sample $(N=970)$

\begin{tabular}{|c|c|c|c|c|c|c|c|c|c|c|}
\hline s EMBU & $\begin{array}{r}\text { Rejection } \\
\text { (F) }\end{array}$ & $\begin{array}{l}\text { Rejection } \\
\text { (M) }\end{array}$ & $\begin{array}{l}\text { n } \\
\text { E warm } \\
\text { 1) }\end{array}$ & $\begin{array}{r}\text { E warm } \\
\text { (M) }\end{array}$ & $\begin{array}{l}\text { Protection } \\
\text { (F) }\end{array}$ & $\begin{array}{l}\text { n Protection } \\
\text { (M) }\end{array}$ & Gender & $\begin{array}{l}\text { My parent } \\
\text { separated }\end{array}$ & $\begin{array}{l}\text { s I have } \\
\text { brothers... }\end{array}$ & $\begin{array}{l}\text { I have...older } \\
\text { brothers }\end{array}$ \\
\hline Rejection (F) & 1 & $.655^{* *}$ & $-.212^{* *}$ & $-.293^{* *}$ & $.345^{* *}$ & .033 & -.020 & .047 & $-.067^{*}$ & $-.126^{* *}$ \\
\hline Rejection (M) & $.655^{*}$ & 1 & $-.068^{\circ}$ & $-.345^{* *}$ & $.318^{* *}$ & -.048 & .014 & .066 & -.047 & -.040 \\
\hline E warm (F) & $-.212^{* *}$ & $-.068^{\circ}$ & 1 & $.643^{* *}$ & $.404^{*}$ & $.405^{* *}$ & -.045 & .027 & -.051 & -.008 \\
\hline E warm (M) & $-.293^{* *}$ & $-.345^{* *}$ & $.643^{*}$ & 1 & $.308^{* *}$ & $.434^{* *}$ & .029 & .086 & -.039 & -.040 \\
\hline Protection (F) & $.345^{* \prime}$ & $.318^{* *}$ & $.404^{* \prime}$ & $.308^{* *}$ & 1 & $.596^{* *}$ & -.008 & .115 & -.038 & $-.122^{* *}$ \\
\hline Protection (M) & .033 & -.048 & $.405^{* \prime}$ & $.434^{* \prime}$ & $.596^{*}$ & 1 & -.037 & .191 & -.028 & -.063 \\
\hline Gender & -.020 & .014 & -.045 & .029 & -.008 & -.037 & 1 & -.069 & $.113^{* \prime}$ & .038 \\
\hline Age & $-.088^{* *}$ & $-.067^{*}$ & .033 & .024 & .000 & .022 & $-.074^{*}$ & $.222^{\circ}$ & $.145^{* *}$ & .038 \\
\hline Ages category & $-.090^{* *}$ & -.060 & .051 & .043 & .020 & .040 & -.016 & $.254^{\circ}$ & $.162^{* *}$ & .054 \\
\hline $\begin{array}{l}\text { I lived (s) with both } \\
\text { parents ... }\end{array}$ & .048 & $.107^{* *}$ & $.091^{* *}$ & -.013 & .066 & .053 & $-.110^{* *}$ & $.346^{* *}$ & .019 & $.073^{\circ}$ \\
\hline My father is... years & -.071 & -.035 & .046 & .023 & -.010 & .019 & $-.106^{*}$ & .204 & $.218^{* *}$ & $.289^{* *}$ \\
\hline My father died ... & .099 & .041 & .129 & .020 & $.193^{*}$ & $.184^{\circ}$ & -.025 & -.076 & -.031 & -.081 \\
\hline My mother is... years & $-.112^{* *}$ & -.021 & .031 & -.011 & -.045 & -.002 & $-.088^{*}$ & $.224^{\circ}$ & $.205^{* *}$ & $.325^{* *}$ \\
\hline My mother died... & -.032 & -.003 & -.052 & -.058 & -.082 & .003 & -.046 & .536 & .111 & .126 \\
\hline My parents separated & .067 & $.184^{\circ}$ & $.200^{\circ}$ & .120 & $.212^{\circ}$ & $.190^{\circ}$ & .059 & $.909^{* *}$ & .119 & .131 \\
\hline I have lived with.... & .047 & .066 & .027 & .086 & .115 & .191 & -.069 & 1 & .073 & .044 \\
\hline I have brothers ... & $-.067^{\circ}$ & -.047 & -.051 & -.039 & -.038 & -.028 & $.113^{*}$ & .073 & 1 & $.588^{* *}$ \\
\hline I have ... older brothers & $-.126^{* *}$ & -.040 & -.008 & -.040 & $-.122^{* *}$ & -.063 & .038 & .044 & $.588^{* *}$ & 1 \\
\hline
\end{tabular}




\section{Acta Technologica Dubnicae \\ volume 6, 2016, issue 3}

We analyzed separately for men and women. For men in the sample, there were positively correlated Rejection of both parents, Emotional warmth of both parents, Overprotection father and Rejection mother scale, Overprotection scale of both parents, there was no correlation with demographic items, families, number of siblings ...

For women in the sample there were significant positive correlations between "My parents separated" and Rejection mother scale $(\mathrm{r}=.337, \mathrm{p}<.001)$; and Emotional warmth father scale $(\mathrm{r}=.272, \mathrm{p}<.001)$; and Overprotection father scale $(\mathrm{r}=.264, \mathrm{p}<.001)$; each highly correlated Rejection father and Rejection mother scale $(r=.626, p<.001)$; Emotional warmth of both parents was $r=.712, p<.001$.

\section{Differences}

There were statistically significant differences between men and women in Scales of father: Rejection $(\mathrm{t}(967)=6.692, \mathrm{p}<0.05, \mathrm{~d}=0.128)$, Emotional warmth $(\mathrm{t}(968)=9.954, \mathrm{p}<0.05, \mathrm{~d}=0.287)$, and further there were statistically significant differences between men and women in Scale of mother: Overprotection $(\mathrm{t}(968)=10.914, \mathrm{p}<0.05, \mathrm{~d}=0.292)$.

Our results of statistically significant differences between Scales of father and ages category are in Table 4. Our results of differences between Scales of mother and ages category were significant than those of father. We had categories: to 30 years, from 31 to 40 years, from 41 to 50 years, over 50 years. All differences between Ages category and Rejection were $d \geq 3.674, p<0.05$; category over 50 years the most score in Rejection father and mother.

Next, we analyzed the relationship between sEMBU scale scores and family status. Statistically significant differences were found between parent families and single parent families, see in Table 5 (father) and see in Table 6 (mother). 
Table 4

Differences between sEMBU scales (father) and ages category in the whole sample $(N=970)$

\begin{tabular}{lrrrrr}
\hline & ANOVA & & & & \\
$\begin{array}{l}\text { sEMBU scales (father) and ages } \\
\text { category }\end{array}$ & \multicolumn{1}{c}{ SS } & df & MS & F & Sig. \\
\hline \multirow{2}{*}{ Rejection (father) } & 275.642 & 3 & 91.881 & 8.915 & $.000^{\mathrm{a}}$ \\
& 9925.202 & 963 & 10.307 & & \\
& 10200.844 & 966 & & & \\
Emotional warmth (father) & 59.888 & 3 & 19.963 & 1.968 & .117 \\
& 9779.463 & 964 & 10.145 & & \\
& 9839.351 & 967 & & & \\
Overprotection (father) & 68.426 & 3 & 22.809 & 1.858 & .135 \\
& 11836.830 & 964 & 12.279 & & \\
\hline
\end{tabular}

Table 5

Differences between sEMBU scales (father) and family status (parent families/ single parent families) in the whole sample $(N=970)$

\begin{tabular}{lrrrc}
\hline \multicolumn{1}{c}{ sEMBU } & $\mathrm{t}$ & $\mathrm{df}$ & Sig. (2-tailed) & Sig. \\
& & & & \\
Rejection (father) & 1.102 & 862 & .271 & $\mathbf{0}$ \\
Emotional warmth (father) & 4.134 & 119.358 & .000 & +++ \\
Overprotection (father) & 3.000 & 120.135 & .003 & ++ \\
\hline
\end{tabular}

Table 6

Differences between sEMBU scales (mother) and family status (parent families/ single parent families) in the whole sample $(N=970)$

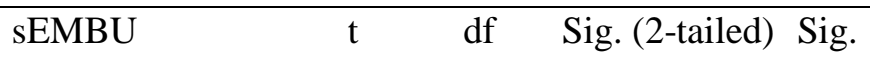

\begin{tabular}{lrrrr} 
Rejection (mother) & 3.806 & 863 & .000 & +++ \\
Emotional warmth (mother) & 2.437 & 863 & .015 & + \\
Overprotection (mother) & 2.482 & 120.875 & & $.014 \quad+$ \\
\hline
\end{tabular}




\section{Acta Technologica Dubnicae \\ volume 6, 2016, issue 3}

Statistically significant differences were found only for Emotional warmth father scale, where the participants from parent families scored higher than those from single parent families, $(\mathrm{t}(970)=.134, \mathrm{p}<0.05, \mathrm{~d}=1.414)$. Further, statistically significant differences were found only for Rejection mother scale, where participants from single parent families scored higher than those from parent families, $(\mathrm{t}(970)=3.806, \mathrm{p}<0.05, \mathrm{~d}=1.362)$. We found differences in evaluation of mothers between men and women, the differences were in items $4,11,12,15$, $18,19,20$, limits, and fears punishment, favoring siblings ...

Several studies found a relationship between Rejection and Emotional warmth (see Arrindell et al., 2001). They found the presence of the following correlations: Rejection with Emotional warmth -.45 and -.46 , respectively in the East-German data and -.46 and -.49 , respectively, in the Swedish data (P's< $0.001)$; Rejection correlated positively with Protection. Similar results were also found by other authors (García, Aluja, \& Del Barrio, 2006) (Saleem \& Mahmood, 2011).

\section{Psychometric properties of sEMBU subscales}

The internal consistency for the subscale were $\alpha=.820$ for our factors of Father (without item no. $9 \alpha=.823$ ) and $\alpha=.856$ for our factors of Mother (without item no. $20 \alpha=.860$ ). The Slovak version of sEMBU seems to be quite reliable. The mean Item-total correlation for Rejection father subscale was from .310 to .652; and for Emotional warmth was from .304 to .752; and Overprotection was from .411 to .709 . Our results were the following: for Rejection mother subscale was from .303 to .762; and for Emotional warmth was from .371 to .616; and Overprotection was from .305 to .672 . Our results are very similar to the results of other studies (see Arrindell et al., 2001).

We analyzed gender differences with point-biserial correlation. Items 9 and 20 showed some differences between males and females (rpbis=>.100). Item 9 had a higher reliability of mother .460 (than father .127); and also in rotation significant nourished by a factor. Item 20 had a higher reliability of father .425 (than mother .030).

A principal component analysis with Varimax rotation was performed on sEMBU (see the Table 7a,b). Keiser-Mayer-Olkin measure was adequate $(\mathrm{KMO}$ (father $)=.820 ; \mathrm{KMO}($ mother $)=.860)$. Bartlett's test of Sphericity was highly significant $(\mathrm{p}<.001)$. Data were suitable for Principal component analysis. Model (see Table 7a) best describes the items 14(.752), 13(-.534), 12(.709) of father and best describes the items 9 (.672), 7 (.762), 23(-.533) of mother (see Table 7b). Item no. 9 for father (see the Table 7a) and no. 20 for mother (see the Table $7 \mathrm{~b}$ ) were the worst was explained. Those items were in the next steps 


\section{Acta Technologica Dubnicae \\ volume 6, 2016, issue 3}

excluded from the analysis. The items of sEMBU were grouped almost identically as the attachment theory behind EMBU assumes.

Table 7a

Pattern matrix and factor loadings of the sEmbu scales (father, $N=970$ )

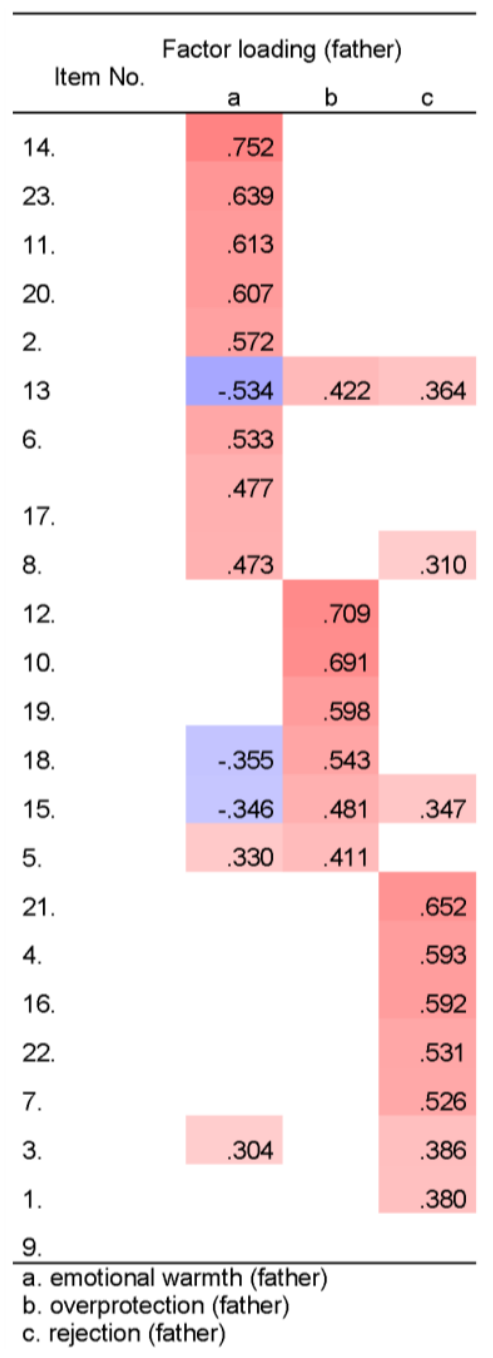

Table $7 b$

Pattern matrix and factor loadings of the sEmbu scales (mother, $N=970$ )

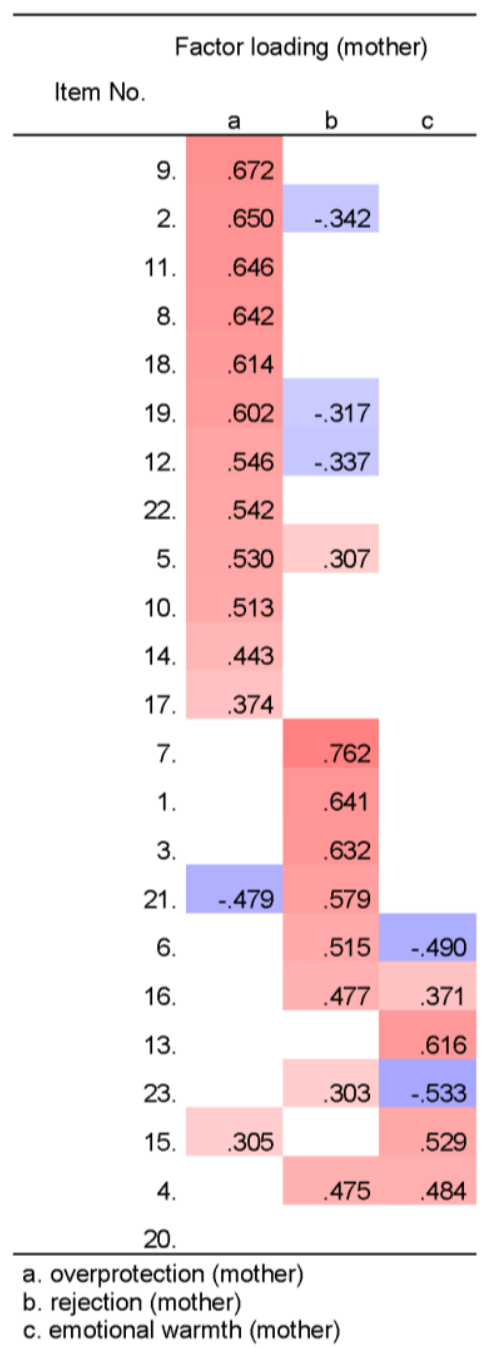




\section{Acta Technologica Dubnicae \\ volume 6, 2016, issue 3}

\section{Conclusions}

The results of our study indicate that the Slovak translation of sEMBU is a reliable instrument for measuring the existing modeling patterns of education in Slovakia. Cronbach's reliability of the Slovak sEMBU was satisfactory $(>.80)$. Although three dimensions of sEMBU: Rejection, Emotional warmth, and Overprotection were originally thought to be independent, most studies find at least a mild correlation between them. The correlation found in our study is comparable to the results obtained by Arrindell et al. (2001) and by others (Bogels, van Oosten, Muris, \& Smulders, 2001). An exploratory analysis using a forced three-factor solution sorted the items of the Slovak version of sEMBU into relevant scales (Rejection, Emotional warmth and Overprotection). There were gender differences in sEMBU scale scores, statistically significant differences were found between parent families and single parent families, for men in the sample, Rejection of both parents was positively correlated - the result commonly found in many research studies.

Although our results present that the Slovak version of sEMBU is a reliable instrument for measuring the existing modeling patterns of education in Slovakia, we recommend to look into the relationship between the Slovak sEMBU and other measures of attachment. Particularly, it would be useful to analyze the relationship between self-report and interview based on behavioral analysis of attachment. Further research on at least short-term temporal stability of the Slovak version of sEMBU is advisable for further information on the reliability of the measure, gender differences and parenting (Richter, \& Eisemann, 2001). It seems that Emotional warmth is an important protective factor and Rejection is a sign of criticizing, shaming and negative expectations.

\section{References}

Ainsworth, M. D. S., Bell, S.M., \& Stayton, D. J. (1975). Infant-mother attachment and social development: Socialisation as a product of reciprocal responsiveness to signal. In M. Richards, The Integration of the Child into a Social World. Cambridge: Cambridge University Press.

Ainsworth, M., Blehar, M., Waters, E., \& Wall, S. (1978). Patterns of attachment: a psychological study of the strange situation. Hillsdale, NJ: Erlbaum.

Arrindell, W. A. et al. (2001). The short-EMBU in East-Germany and Sweeden: A cross-national factorial validity extension. Scandinavian Journal of Psychology, 42, 157-160.

Arrindell, W. A., Emmelkamp, P. M. G., Brilman, E., \& Monsma, A. (1983). Psychometric evaluation of an inventory for assessment of parental rearing practices: a Dutch form of the EMBU. Acta Psychiatrica Scandinavica, 67, 163-177. 


\section{Acta Technologica Dubnicae \\ volume 6, 2016, issue 3}

Arrindell, W. A., Emmelkamp, P. M. G., Monsma, A., \& Brilman, E. (1983). The role of Perceived Parental Rearing Practices in the Aetiology of Phobic Disorders: A controlled study. The British Journal of Psychiatry, 143, 183187.

Arrindell, W. A., Sanavio, E., Aguilar, G., Sica, C., Hatzichristou, Ch., Eisemann, M., Recinos, L. A., Gaszner, P., Peter, M., Battagliese, G., Kallai, J., \& Van Der Ende, J. (1999). The development of a short form of the EMBU: Its appraisal with students in Greece, Guatemala, Hungary and Italy. Personality and individual Differences, 27, 613-628.

Bogels, S. M., van Oosten, A., Muris, P., \& Smulders, D. (2001). Familial correlates of social anxiety in children and adolescents. Behaviour and Therapy, 39, 273-287.

Bowlby, J. (1969). Attachment and loss: vol. 1. In J. Bowlby, Attachment. Basic Books. New York.

Bowlby, J. (1991). Charles Darwin: A new biography. London: Hutchinson.

Castro, J., de Pablo, J., Gómez, J., Arrindell, W. A., \& Toro, J. (1997). Assessing rearing behaviour from the perspective of the parents: a new form of the EMBU. Social Psychiatry and Psychiatric Epidemiology, 32, 230-235.

Eisemann, M., Perris, C., Perris, H., \& von Knorring, L. (1984). Perceived parental rearing practices in depressed patients in relation to social class. Acta psychiatrica scandinavica, 70, 568-572.

García, L. F., Aluja, A., \& Del Barrio, V. (2006). Effects of personality, rearing styles and social values on adolescents' socialisation process. Personality and Individual Differences, 40(8), 1671-1682.

Hašto, J. (2005). Vztahová väzba. Ku koreňom lásky a úzkosti. Bratislava: Vydavatel'stvo F.

Jacobson, L., Lindstrom, H., von Knorring, L., Perris, C., \& Perris, H. (1980). Perceived Parental Behaviour and Psychogenic Needs. Archiv fur Psychiatrie und Nervenkrankheiten Archives of Psychiatry and Neurological Sciences, 228, 21-30.

Livianos-Aldana, \& L., Rojo-Moreno, L. (2003). Construct validity of retrospective perception of parental relating scales: EMBU and PBI. Personality and Individual Differences, 35, 1707-1718.

Mojžišová, V. (2006). The issue of attachment in adult psychiatric patients with depressive and anxiety disorders [Attestation work, specialization in Clinical Psychology]. Bratislava.

Oldehinkel, A. J., Veenstra, R., Ormel, J., de Winter, A. F., \& Verhulst, F. C. (2006). Temperament, parenting, and depressive symptoms in a population sample of preadolescents. Journal of Child Psychology and Psychiatry, 47(7), 684-695.

Perris, C., Arrindell, W. A., van der Ende, J., Maj, M., Benjaminsen, S., Ross, M., Eisemann, M., \& del Vecchio, M. (1985). Cross-national study of 


\section{Acta Technologica Dubnicae \\ volume 6, 2016, issue 3}

perceived parental rearing behaviour in healthy subjects from Australia, Denmark, Italy, The Netherlands and Sweden: pattern and level comparisons. Acta psychiatrica scandinavica, 72, 278-282.

Perris, C., Jacobson, L., Lindstrom, H., Von Knorring, L., \& Perris, H. (1980). Development of a new inventory for assessing memories of parental rearing behaviour. Acta psychiatrica Scandinavica, 61, 265-274.

Poliaková, M., Mojžišová, V., \& Hašto, J. (2007). Skrátený dotazník zapamätaného rodičovského správania ako výskumný klinický nástroj s.E.M.B.U. Psychiatria-Psychosomatika, 14, 79-88.

Richter, J., \& Eisemann, M. (2001). Stability of Memories of Parental Rearing amnong Psychiatric Inpatients: A Replication Based on EMBU Subscales. Psychopathology, 34, 318-325.

Rojo-Moreno, L., Livianos-Aldana, L., Cervera-Martínez, G., \& DominguezCarabantes, J. A. (1999). Rearing style and depressive disorder in adulthhood: a controlled study in a Spanish clinical sample. Soc Psychiatry Psychiatr Epidemiol. 34, 548-554.

Saleem, S., \& Mahmood, Z. (2011). Development of a scale for assessing emotional and behavioral problems of school children. Pakistan Journal of Social and Clinical Psychology, 9(2), 73-78. 